JURNAL ILMIAH KOMPUTERISASI AKUNTANSI, Vol. 13, No. 2, Desember 2020, pp. 11 - 20

p-ISSN : 1979-116X (print)

e-ISSN : 2614-8870 (online)

http://journal.stekom.ac.id/index.php/kompak

- page 11

\title{
SISTEM INFORMASI PEMBELIAN DAN PENGELUARAN KAS PADA CV.ANGKASA BARU
}

\author{
Siswanto Siswanto ${ }^{1}$, Maya Utami Dewi ${ }^{2}$, Lutfi Anggraini ${ }^{3}$, Agustinus Budi Santoso ${ }^{4}$ \\ ${ }^{1}$ Sstem Komputer - Universitas STEKOM, siswanto@stekom.ac.id \\ ${ }^{2,4}$ Sistem Informasi - Universitas STEKOM maya@ymail.com, agus@stekom.ac.id \\ ${ }^{3}$ Komputer Akuntansi - Universitas STEKOM, lutfi@ymail.com \\ J1. Majapahit 605, Semarang, telp/fax : 024-6717201-02
}

\begin{tabular}{l}
\hline ARTICLE INFO \\
\hline Article history: \\
Received 30 November 2020 \\
Received in revised form 2 Desember 2020 \\
Accepted 10 Desember 2020 \\
Available online 15 Desember 2020
\end{tabular}

Available online 15 Desember 2020

\section{ABSTRACT}

The information system for purchases and cash disbursements is one of the entire information systems. In retail sales companies need control of purchases and cash disbursements that are precise and fast. In an effort to minimize sudden out-of-stock inventory, it is necessary to secure an inventory to cope with a sudden out of stock due to delays in purchasing goods that occur at CV. New Space. This is what encourages the author to conduct research on CV. Angkasa Baru and choose the title "Purchasing Information System and Cash Distribution at CV. New Space.

In writing this research systemin formation, the author uses the Microsoft Visual Basic 6.0 application, the research writing method uses the Research and Development (R\&D) model, while the stages of this research model go through the stages of observation or interviews with parties related to the data required in writing this thesis, stages of designing the application system, designing specifications, validation test stages, revision of validation until the system passes. The development method used by the author is the prototype method, where the system created will be tailored to the needs of the user, if there is a change in the system it will be repaired until the user is satisfied with the system.

Keywords: Information systems, purchases, safety expenditures, inventory safety.

\footnotetext{
ABSTRAK

Sistem informasi pembelian dan pengeluaran kas merupakan salah satu dari keseluruhan sistem informasi yang. Dalam perusahaan penjualan retail membutuhkan pengendalian pembelian dan pengeluaran kas yang tepat dan cepat. Dalam upaya menimimalkan kehabisan stok persediaan secara mendadak, perlu adanya pengaman persediaan untuk menanggulangi kehabisan stok persediaan secara mendadak akibat keterlambatan pembelian barang yang terjadi pada CV. Angkasa Baru. Hal ini yang mendorong penulis untuk melakukan penelitian pada CV. Angkasa Baru dan memilih judul "Sistem Informasi Pembelian dan Pengeluran Kas pada CV. AngkasaBaru.

Dalam penulisan penelitian sistemin formasi ini, penulis menggunakan aplikasi Microsoft Visual Basic 6.0, metode penulisan penelitian menggunakan model Research and Development (R\&D), adapun tahapan model penelitian ini melalui tahapan observasi atau wawancara terhadap pihak yang terkait dengan data yang diperlukan dalam penulisan skripsi ini, tahapan merancang sistem aplikasi, merancang spesifikasi, tahapan uji validasi, revisi validasi hingga sistem dinyatakan lulus. Metode pengembangan yang
}

Received November 30, 2020; Revised November 10, 2020; Accepted Desember 06, 2020 
digunakan oleh penulis ialah metode prototype, dimana sistem yang dibuat akan disesuaikan dengan kebutuhan pengguna, apabila ada perubahan dalam sistem akan dilakukan perbaikan sampai pengguna merasa puas dengan sistem tersebut.

Kata Kunci : Sisteminformasi, pembelian, pengeluarankas, pengamanpersediaan.

\section{Pendahuluan}

Pembelian merupakan transaksi penting perusahaan yang harus mematuhi kebijakan dasar manajemen. Dalam melaksanakan transaksi pembelian, pembelian harus mampu memberikan kontribusi optimum kepada manajemen perusahaan sebagai bagian penting dalam upaya mencapai target profit yang ditetapkan manajemen. Menurut Hery (2011) dalam buku "Akuntansi", menyatakan kas meliputi uang logam, uang kertas, cek, wesel pos, dan deposito. Kas merupakan aktiva yang paling lancar dibanding aktiva lainnya.Oleh sebab itu, kas merupakan aktiva yang paling digemari untuk dicuri, dimanipulasi, dan diselewengkan.Pada umumnya kas dikeluarkan untuk berbagai tujuan (alasan), seperti membayar beban beban tertentu serta untuk membeli barang dagangdari suplier. Sistem informasi akuntansi adalah sebuah sistem yang memproses data dan transaksi untuk menghasilkan informasi yang bermanfaat untuk merencanakan, mengendalikan, dan mengoperasikan bisnis (Krismiaji, 2005).

$\mathrm{CV}$. Angkasa Baru merupakan salah satu perusahaan yang menjual komponen komputer, dan laptop di Jawa Tengah. CV. Angkasa Baru berdiri sejak 12 Tahun yang lalu, yang beralamat dijalan Wonodri Baru no. 66 Semarang. Selama ini perusahaan dalam melakukan proses sehari - hari masih dengan sistem manual yaitu pencatatan stok barang dagang masih menggunakan pencatatan tulis manual oleh bagian gudang, kemudian stok barang dagang yang sudah menipis akan diajukan permintaan kebutuhan persediaan oleh bagian gudang kepada pembelian, kemudian bagian pembelian melakukan pembelian barang dan pengelolaan barang, bagian pembelian dalam hal ini bertanggung jawab meliputi proses perencanaan, pemilihan perusahaan suplier, kalkulasi dan penetapan harga. pada CV. Angkasa Baru dan menjamin keamanan data pada proses tersebut. Penggunaan sistem ini dengan cara menggunakan program aplikasi sistem informasi pembelian dan pengeluaran kas yang berbasis terhubungnya jaringan komputer Client ke komputerServer.Dimana komputer Server yang terhubung dengan komputer client pada bagian gudang, bagian pembelian, bagian keuangan dan pimpinan. Sistem informasi menggunakan visual basic ini diharapkan dapat membantu bagian pembelian dalam menghitung kebutuhan persediaan secara cepat dan akurat,sehingga mampu memenuhi permintaan kebutuhan persediaan pada periode tertentu, sistem informasi pembelian dan pengeluaran kas ini dilengkapi catatan tanggal jatuh tempo sehingga memudahkan bagian keuangan dalam mengingat kapan waktu tanggal jatuh tempo hutang dagang, pada sistem pengeluaran kas dapat meminimalkan resiko kesalahan pencatatan yang timbul dalam pengeluaran kas, serta keamanan penyimpanan data dapat terjamin menggunakan SQL server sebagai database.

\section{Landasan Teori}

Pembelian merupakan transaksi penting perusahaan yang harus mematuhi kebijakan dasar manajemen.Dalam melaksanakan transaksi pembelian, pembelian harus mampu memberikan kontribusi optimum kepada manajemen perusahaan sebagai bagian penting dalam upaya mencapai target profit yang ditetapkan manajemen.Pembelian merupakan bagian proses penting dari sebuah perusahaan yang bertanggung jawab terhadap pengadaan dan pengelolaan barang (Agus Supriyanto dan Ida Masruchah, 2008).

Menurut Rian Suhardiyanto (2015), kas adalah uang tunai yang paling likuid sehingga pos ini biasanya ditempatkan pada urutan teratas sari aset. Kas merupakan alat aktiva lancar yang meliputi uang kertas atau logam dan benda - benda lain yang dapat segera diuangkan sebesar nilai nominalnya dan dapat digunakan untuk membayar utang jangka pendek

Menurut Hery ( 2011), menyatakan kas merupakan aktiva yang paling lancar dibanding aktiva lainnya. Oleh sebab itu, kas merupakan aktiva yang paling digemari untuk dicuri, dimanipulasi, dan diselewengkan.kas meliputi uang logam, uang kertas, cek, wesel pos, dan deposito. Pada umumnya kas dikeluarkan untuk berbagai tujuan (alasan), seperti membayar beban - beban tertentu serta untuk membeli barang dagang dari suplier.Pengeluaran kas pada perusahaan biasanya dilakukan menggunakan uang kas dan cek, dimana kas kecil disediakan untuk membayar pengeluaran - pengeluaran kecil dan tidak ekonomis bila dibayar dengan cek. Seperti halnya ongkos transport atau pembelian barang yang nominal harga relatif kecil dan kuantiti sedikit dimana pembayaran dengan cek untuk hal - hal sekecil itu akanmengakibatkan pekerjaan menjadi tidak efisien

JURNAL ILMIAH KOMPUTERISASI AKUNTANSI Vol. 13, No. 2, Desember $2020: 1$ - 9 
Visual basic 6.0 merupakan bahasa pemrograman yang cukup popular dan mudah untuk dipeljari. Anda dapat membuat program dengan aplikasi gui atau program yang menungkinkan pemakai computer berkomunikasi dengan computer tersebut dengan menggunkan modus grafik atau gambar. (Madcoms: 2010)

SQL sering dirujuk sebagai bahasa query. SQL dapat melakukan lebih dari sekedar melakukan query pada basiss data. SQL dapat digunakan untuk mendefinisikan struktur data, memodifikasi data pada babsis data, menspesifikasi batasan keamanan (security), hingga ke pemeliharaan kinerja basis data dan pengaturan pemrosesan pada CPU (Central Processing Unit) paralel.SQL adalah query yang biasa digunakan untuk mendefinisikan relasi antar tabel yang ada. (M. Miftakul Amin, 2012)

Client Server Menurut MADCOM (2010), semakin berkembangnya kebutuhan pengolahan data dan informasi, didalam sebuah perusahaan dibutuhkan beberapa komputer yang digunakan oleh banyak orang yang bekerja dalam sebuah tim. Untuk saling bertukar data dan informasi, maka komputer komputer yang digunakan akan terhubung antara satu dengan yang lainya. Kumpulan komputer yang saling terhubung disebut sebagai jaringan komputer

\section{Metodologi}

Metodologi penelitian adalah metode yang akan digunakan dalam melakukan penelitian. Dalam penyusunan skripsi ini akan digunakan metode sebagai berikut:

a. Obyek Penelitian

Yang menjadi tempat penelitian ini adalah pembelian dan pengeluaran kas di Angkasa Baru beralamat dijalan Wonodri Baru no. 66 Semarang.

Jenis Data. Berdasarkan sumber data yang diperoleh, maka jenis data dapat menggunakan dua sumber dara yaitu :

1. Data Primer adalah data yang diperoleh dari penelitian secara langsung terhadap objek penelitian yaitu memasukkan data Angkasa Baru.

2. Data Sekunder adalah data yang terlebih dahulu dikumpulkan dan dilaporkan oleh orang, dari literatur perusahaan atau yang diperoleh dari perpustakaan berupa pengertian dan konsep dan definisi-definisi, meliputi kegiatan perusahaan, struktur organisasi perusahaan.

b. Metode pengumpulan data

Dalam pembuatan proposal ini perlu dilakukan suatu usaha pengumpulan data, dan data tersebut yang akan digunakan sebagai alat untuk memecahkan masalah yang ada didalamnya. Untuk itu diperlukan beberapa metode yang diperlukan dalam pengumpulan data tersebut, yaitu:

1. Pengamatan (observasi)

Untuk hal ini penulis mengadakan pengamatan langsung mengenai pembelian dan pengeluaran kas di Angkasa Baru beralamat dijalan Wonodri Baru no. 66 Semarang.

2. Wawancara (interview)

Untuk hal ini penulis melakukan pencarian data melalui Tanya jawab di di Angkasa Baru beralamat dijalan Wonodri Baru no. 66 Semarang seperti meliputi proses perencanaan, pemilihan perusahaan suplier, kalkulasi dan penetapan harga pembayaran invoice bagian keuangan akan mencatat semua pengeluaran kas dan membuat laporan pengeluaran kas

3. Metode pengembangan sistem

Metode yang digunakan adalah prototyping yaitu satu versi dari sebuah sistem potensial yang memberikan ide bagi para pengembang dan calon pengguna, bagaimana sistem akan berfungsi dalam bentuk yang telah selesai.

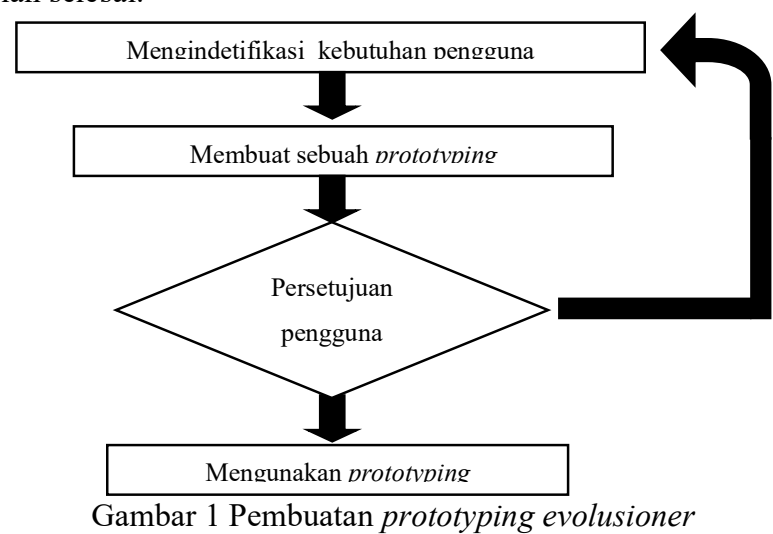


4. Mengindetifikasi kebutuhan pengguna

Mengumpulkan masalah-masalah yang terjadi Angkasa Baru beralamat dijalan Wonodri Baru no. 66 Semarang, tentang Sistem Informasi Pembelian dan Pengeluaran Kas, Bentuk laporan pengeluaran kas.

5. Membuat sebuah prototyping

Menyiapkan rancangan Flowchart, DFD, Normalisasi, ERD, Visual Basic 6.0, User Interface (Form), database SQL Server.

6. Persetujuan pengguna

Setelah materi terkumpul semua tahapan selanjutnya adalah Perancangan Sistem Informasi Akuntansi Informasi Pembelian dan Pengeluaran Kas dengan membuat desain aplikasi yang berisi : Flowchart, DFD, Normalisasi, ERD, Visual Basic 6.0, User Interface (Form), database SQL Server, dan pembuatan kode aplikasi.

7. Mengunakan prototyping

Perancangan Sistem Informasi Pembelian dan Pengeluaran Kas , tapi apabila valid program dapat digunakan sebagai produk prototype sistem informasi yang nanti dapat di implementasikan kepada user yaitu gudang, pembelian, keuangan dan pimpinan, dengan penambahan hak akses user untuk pembatasan pemakai sistem informasi. Setelah melalui tahap uji coba dan hasilnya baik maka prototyping siap digunakan oleh user.

\subsection{Bahan Penelitian}

a. Hardware antara lain :

1. CDROM RW (Read \&Write) LG

2. Monitor 15 inc $L G$

3. HDD (Hard Disk Drive) 500 GB SATA

4. Keyboard USB Logitech K120 dan Mouse PS/2 Logitech

5. Menggunakan Jaringan Komputer Berbasis Client Server

6. Proccesor Pentium 3,00 GHz

7. RAM (Random Access Memory) 4 GB

b. Software antara lain :

1. Sistem Operasi Windows 7 Ultimate 34-bit

2. Microsoft Visual Basic 6.0

3. SQL Server sebagai tempat menyimpan database

1. Form yang dibutuhkan aplikasi ini adalah sebagai berikut :

a. Identifikasi Data

1) Data Barang

2) Data Supplier

3) Data Jual

4) Data Beli

5) Data Jurnal

b. Identifikasi Informasi

1) Laporan Supplier

2) Laporan Persediaan

3) Laporan Pembelian

4) Laporan Penjualan

5) Laporan Data Barang

2. Identifikasi Sumber Data dan Informasi

a. Identifikasi Sumber Data

1) Gudang

2) Supplier

3) Pelanggan

3. Identifikasi Tujuan Informasi

a. Gudang

b. Pembelian

c. Pimpinan

d. Keuangan

JURNAL ILMIAH KOMPUTERISASI AKUNTANSI Vol. 13, No. 2, Desember 2020 : 1 - 9 
3.1 Bahan Penelitian

1. DFD Level 0

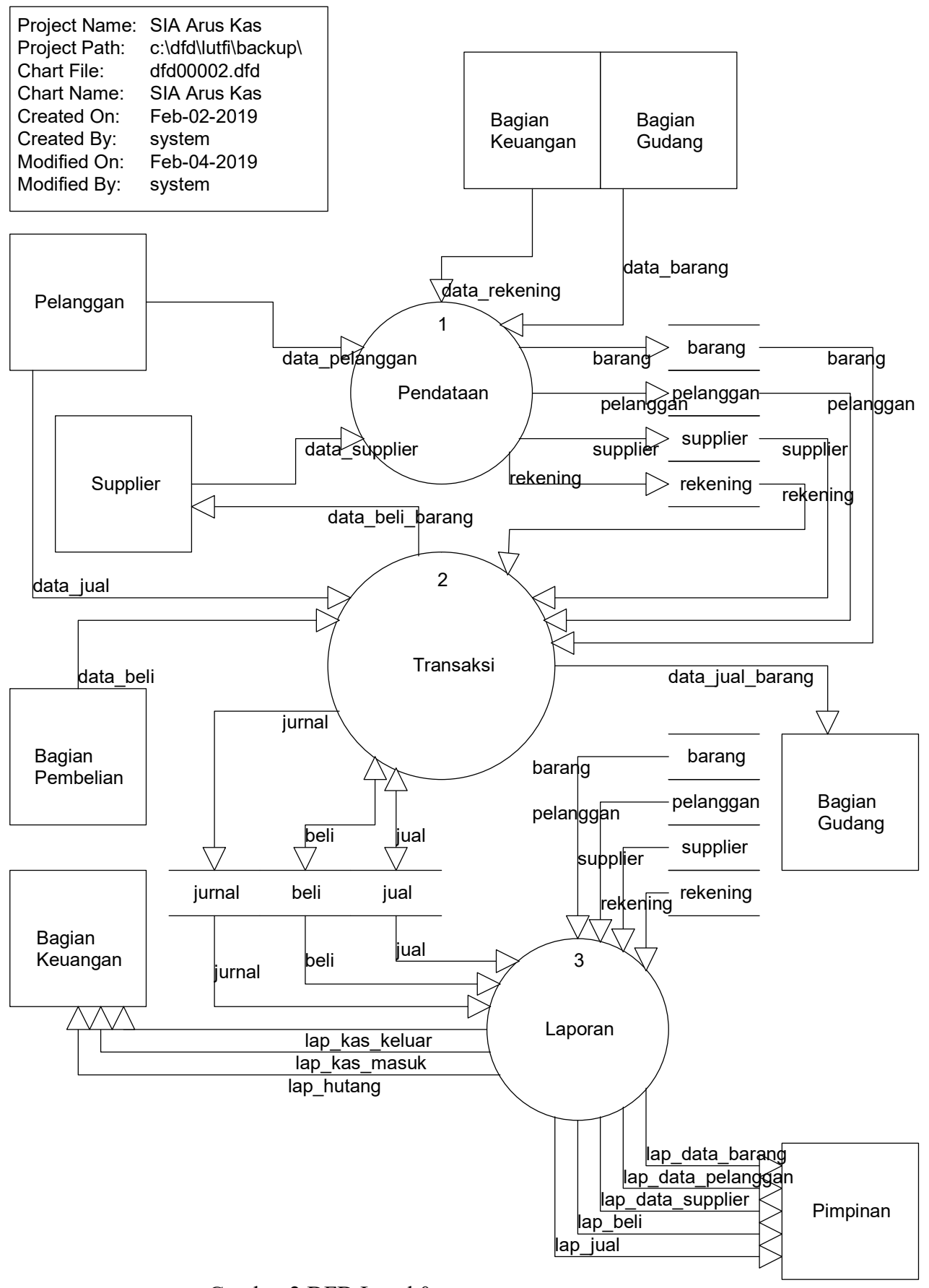

Gambar 2 DFD Level 0

Pada gambar DFD level 0 diatas menjelaskan tentang sistem informasi pembelian dan pengeluaran kas yang dibagi menjadi tiga bagian yaitu pendataan, proses dan laporan. Pada pendataan menghasilkan data rekening, data suplier, data pelanggan, dan data barang yang disimpan pada data store rekening, suplier, pelanggan, dan barang. 
2. FD Level 1 Proses 1 Pendataan

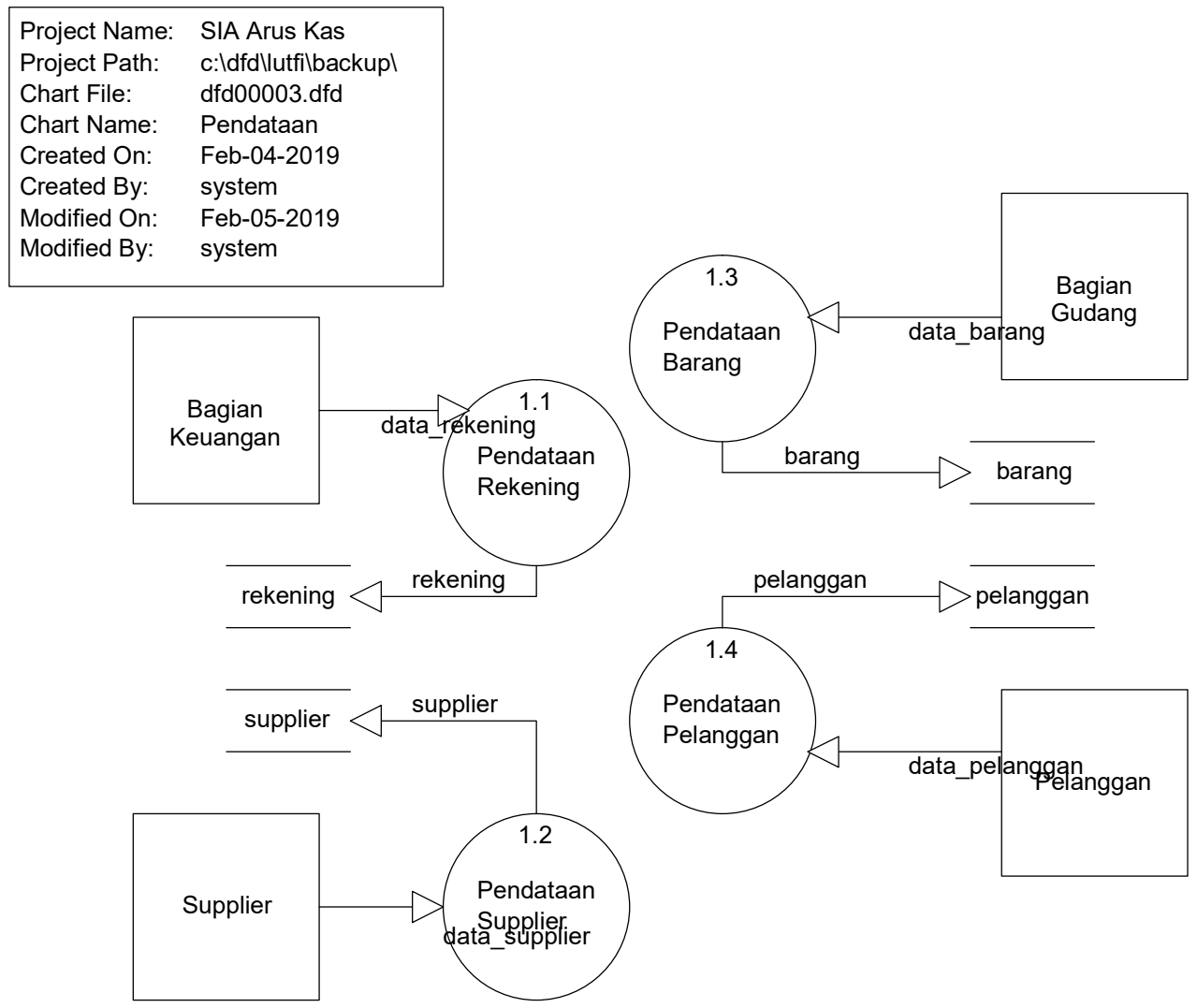

Gambar 3 DFD Level 1 Proses 1 Pendataan

DFD level 1 pendataan merupakan penjabaran dari DFD level 0 pada bagian pendataan, yang mana proses pendataan dijabarkan lagi menjadi pendataan rekening yang didapat dari input data rekening yang akan menghasilkan data store rekening, pendataan suplier yang didapat dari input data suplier yang akan menghasilkan data store suplier, pendataan barang yang didapat dari input data barang yang akan menghasilkan data store barang, pendataan pelanggan yang didapat dari input data pelanggan yang akan menghasilkan data store pelanggan

\subsection{Perancangan}

Membuat perancangan dimana langkah-langkahnya adalah :

1) Menentukan tujuan sistem

2) Membuat spesifikasi produk

3) Menyusun gambaran sistem rancangan program berupa Basis Data, Normalisasi, Diagram Konteks, Flowchart, DFD, ERD dan perancangan database serta perancangan user interface form-form tampilan yang akan dipergunakan dalam aplikasi tersebut. Membuat program, yaitu dengan pembuatan source code dengan menggunakan bahasa pemrograman Visual Basic 6.0.

JURNAL ILMIAH KOMPUTERISASI AKUNTANSI Vol. 13, No. 2, Desember $2020: 1-9$ 


\section{Hasil dan Pembahasan}

\section{Form Login}

Fungsi : Untuk pengamanan aplikasi dengan pembagian hak akses untuk pembelian, bagian gudang, keuangan dan pimpinan.

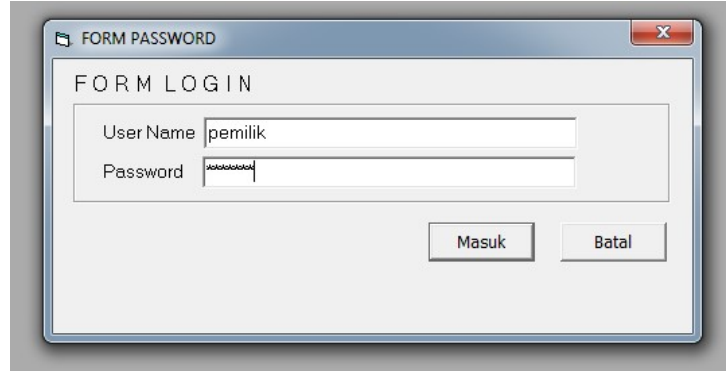

Gambar 4 Form Login

\section{Form Menu Utama}

Fungsi : Untuk Mempermudah User dalam membuka Form Master, Transaksi dan Laporan-laporan.

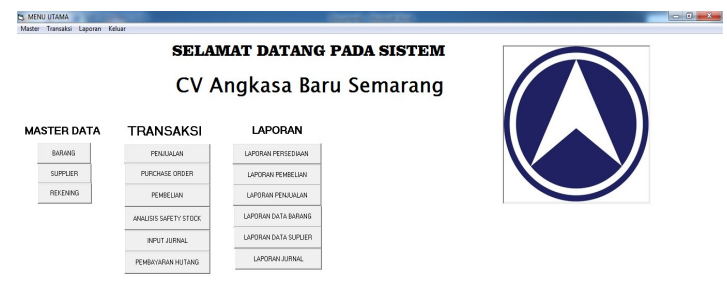

Gambar 5 Form Menu Utama

\section{Form Barang}

Fungsi : Untuk penginputan berfungsi untuk melakukan input, edit dan hapus data barang

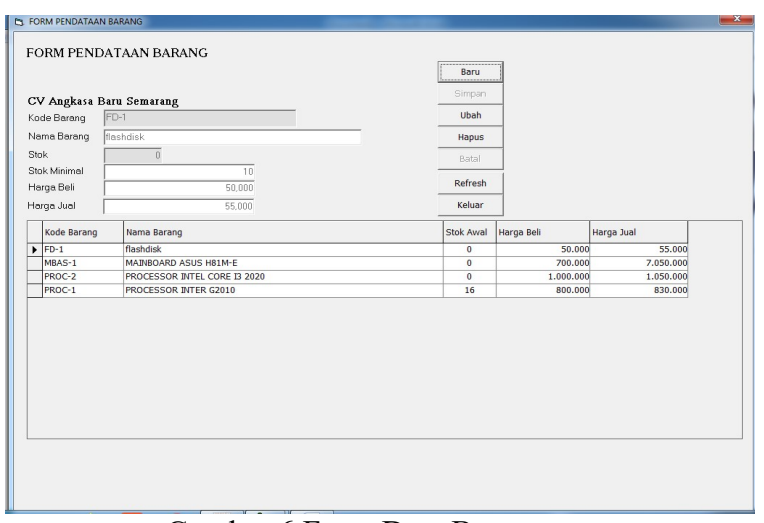

Gambar 6 Form Data Barang 


\section{Form Data Supplier}

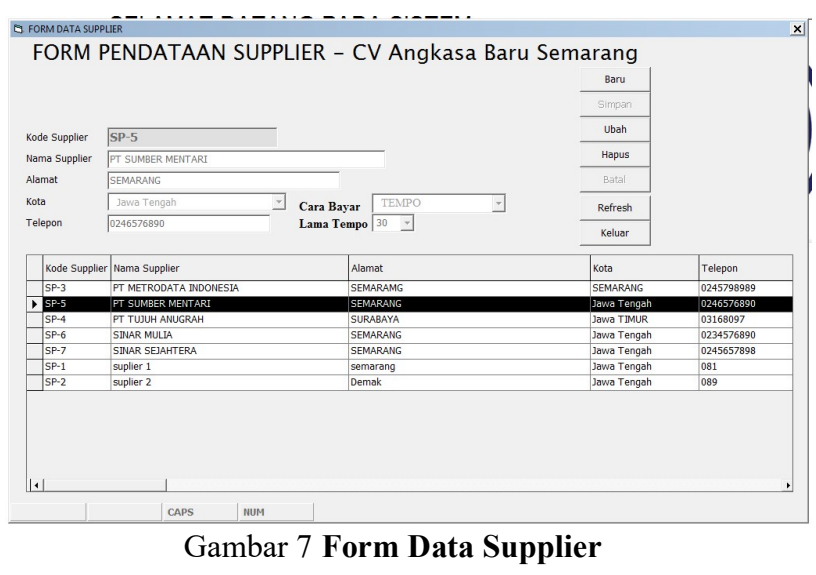

\section{Form Transaksi Penjualan}

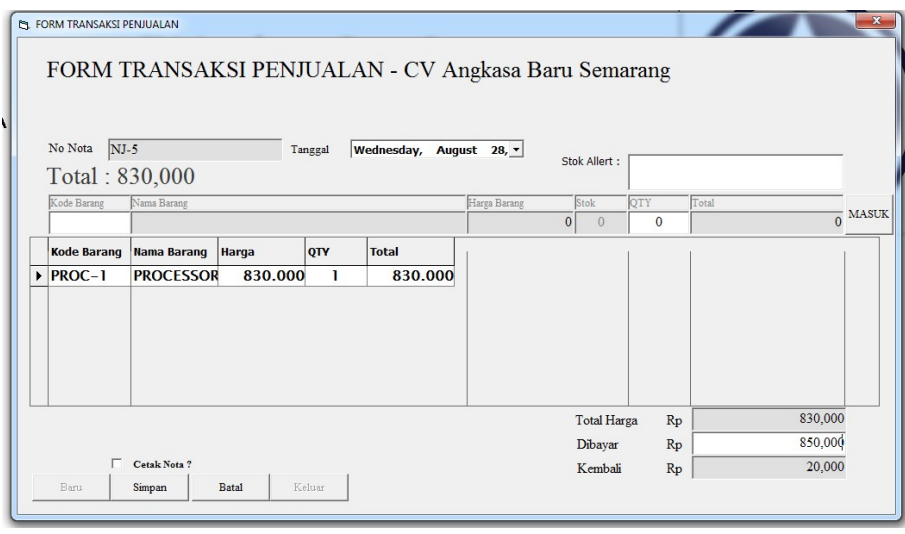

Gambar 8 Form Transaksi Penjualan

\section{Form Pembayaran Hutang}

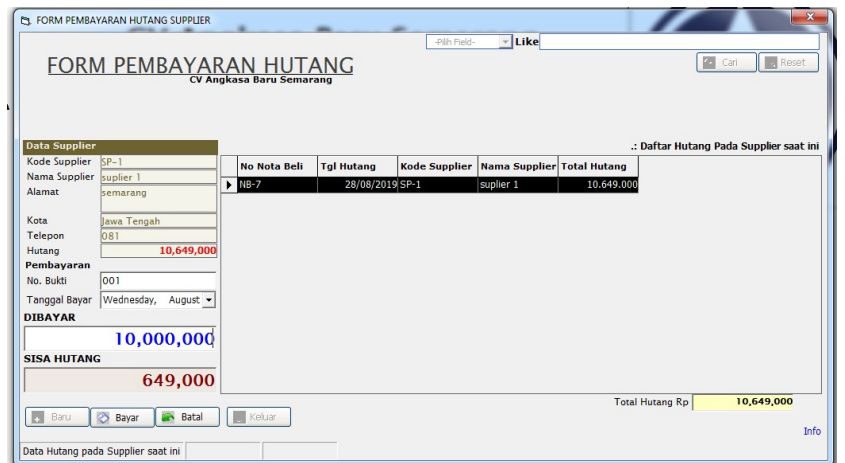

Gambar 9 Form Pembayaran Hutang

JURNAL ILMIAH KOMPUTERISASI AKUNTANSI Vol. 13, No. 2, Desember $2020: 1$ - 9 


\section{Form Laporan Persediaan}

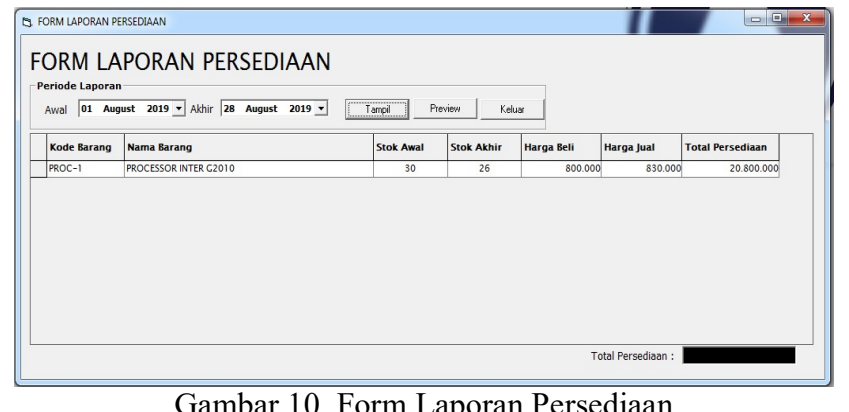

Gambar 10 Form Laporan Persediaan

8. Form Laporan Penjualan

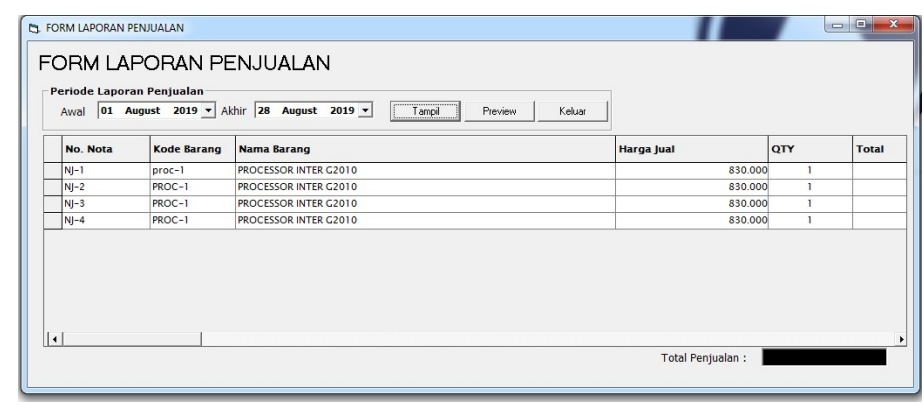

Gambar 11 Form Laporan Penjalan

9.Form Laporan Pembelian

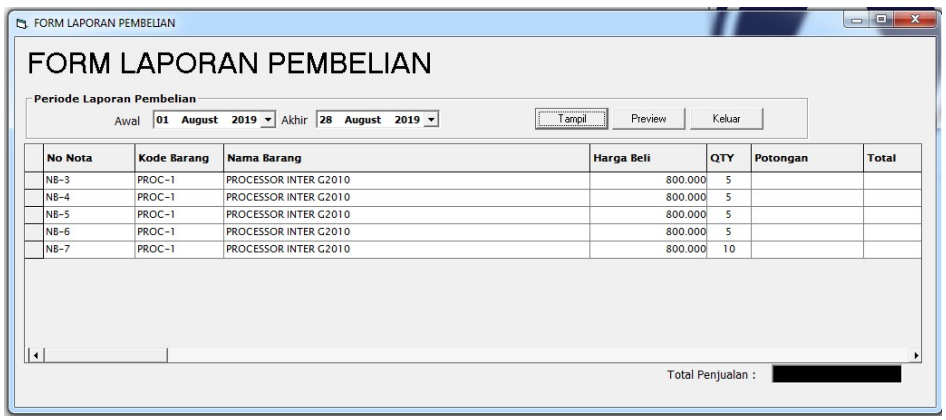

Gambar 12 Form Laporan Pembelian 
10. Form Laporan Jurnal

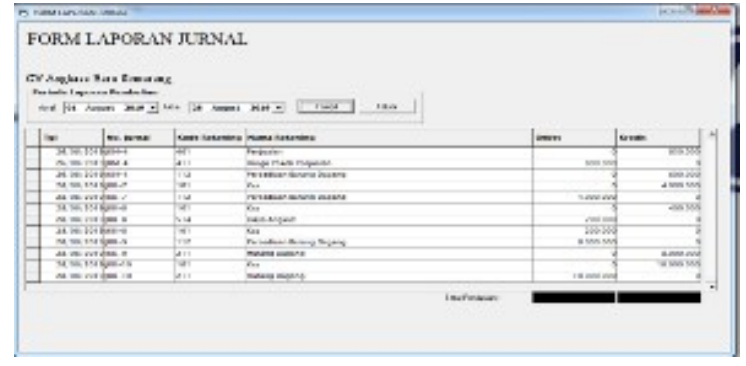

Gambar 13 Form Laporan Jurnal

\section{Kesimpulan}

Pada sistem lama perhitungan kebutuhan persediaan masih dilakukan secara manual dengan alat hitung sederhana yaitu kalkulator, serta rumus yang digunakan untuk perhitungan kebutuhan persediaan yaitu rumus pengurangan sederhana berdasarkan bayangan perkiraan stok. Untuk pencatatan invoice pembelian hanya dilakukan secara sederhana atau ditulis pembelian lunas atau kredit. Pencatatan pengeluaran kas dan pembayaran hutang hanya dicatat dalam laporan excel sederhana, sehingga seringkali pencatatan pengeluaran ditulis dobel dan sebaliknya.

Pengeluaran tidak dilakukan pencatatan pengeluaran kedalam excel serta rawan akan kehilangan data ketika suatu bagian perusahaan akan memberikan data kepada bagian lain sesuai alur kerja pada perusahaan tersebut.

\section{Daftar Pustaka}

Suhardiyanto, Rian., 2015; "Cara Cepat Menguasai Dasar Akuntansi Perkantoran Otodidak Tanpa Guru", Jakarta : Vicosta Publishing,.

Hery, 2011; “Akuntansi :Aktiva, Utang, dan Modal”, Yogyakarta : Gava Media,.

Krismiaji, 2005; "SistemInformasiAkuntansi”, Yogyakarta : UPP AMP YKPN,.

MADCOMS, 2010; "SistemJaringanKomputerUntukPemula", Yogyakarta: CV. Andi Offset,.

Amin, Miftakul, 2012 ; "Pemprograman Database Visual Basic 6.0 dan SQL Server 2000”, Yogyakarta : CV. Andi Offset,

Supriyanto, Agus\&Masruchah, Ida, 2008; “Konsep\&AplikasiManagemen Purchasing”, Jakarta : PT. Elex Media Komputindo,. 